\title{
Implementing the teaching/learning of oral skills in secondary education in Aragón: Gauging teachers' attitudes, beliefs and expectations
}

\author{
RAMÓN Plo, ANA Hornero \& PILAR MuR-DueÑAS* \\ Universidad de Zaragoza
}

Received: 22/05/2013. Accepted: 27/11/2013.

\begin{abstract}
Current national curricula, the Common European Framework of Reference for Languages, and EFL materials highlight the importance of the students' development of oral skills. This study stems from a cross-sectional survey of the teaching of oral skills in Secondary Education in a Spanish local context (Aragón) carried out in 2012 on both teachers and students of English. The present paper focuses on the answers obtained from the group of teachers in order to provide a snapshot of their attitudes, beliefs and expectations regarding the teaching, learning and assessment of oral skills, as well as the implementation of some measures aimed at increasing the required level of oral competence in the foreign language. Teachers' answers reveal that in spite of what is indicated in language policies, oral skills are not sufficiently practiced and/or assessed; that students are still reluctant to engage in oral activities and do not, therefore, reach the required level in these skills.
\end{abstract}

KEYWORDS: oral skills, teaching methodologies, resources, activities, assessment.

\section{RESUMEN}

Tanto el MCERL como los programas y materiales docentes de Inglés como Lengua Extranjera reflejan la creciente importancia concedida a las destrezas orales en el aprendizaje de los estudiantes. Nuestro estudio parte de un análisis transversal de la enseñanza de las destrezas orales en Educación Secundaria en Aragón (España), realizado en 2012 a docentes y estudiantes de inglés. El presente artículo se centra en las respuestas de los profesores, revelando sus actitudes y expectativas en torno al aprendizaje y la evaluación de las destrezas orales. Analiza asimismo la aplicación de ciertas medidas para mejorar el nivel de competencia oral en la clase de lengua extranjera. Las respuestas de los profesores revelan que, a pesar de las medidas conducentes a su implementación en el aula, la práctica y evaluación de las destrezas orales sigue pareciendo insuficiente; que los alumnos no muestran, por diversas razones, el necesario interés por este tipo de actividades y que, por tanto, no se alcanzan los niveles y resultados requeridos.

PALABRAS CLAVE: destrezas orales, metodologías docentes, recursos, actividades, evaluación.

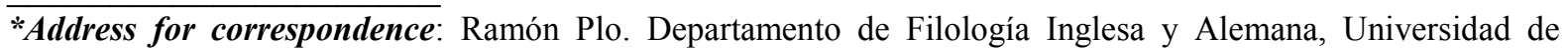
Zaragoza, Zaragoza, Spain; e-mail: plo@unizar.es. 


\section{INTRODUCTION}

In the last few years, there has been a growing interest in the teaching of oral skills in Secondary Education in Spain. This general trend, particularly noticeable in the field of Foreign Language teaching, may well be the result of a number of factors such as the widespread adoption of the communicative method of teaching languages, a greater exposure of students to the foreign language -both in and out of the classroom (language academies, summer courses, study stays in other countries, availability of radio and TV in a foreign language, etc.)- as well as considerably better preparation and specialization on the part of the teachers which has led to more participative classes (Plo \& Pérez-Llantada, 2010: 309). This enhanced interest is in line not only with the European Commission's target of fostering "multilingualism" (or practical skills in at least two languages in addition to one's mother tongue) but also with the increasing -and more specific- academic demands made on students such as the assessment of oral skills in a foreign language as part of the new Schoolleaving / University entrance exams or the shift from B1 to B2 (CEFRL) as the minimum required level of competence in some Spanish universities.

Studies on the learning and acquisition of English as a Foreign Language (EFL) in general and of oral skills in particular have been mostly carried out in bilingual regions in Spain: Galicia (i.e. Palacios 1995; 2002), the Basque Country (i.e. Cenoz 2009; García Mayo et al. 2005) and Catalonia (i.e. Tragant and Muñoz, 2000; Muñoz 2003). These studies focus on multilingualism and the acquisition of English as a third language in their contexts of education.

The overall purpose of our work was to undertake a parallel analysis related to the specific needs of Aragón ${ }^{1}$. This is a predominantly monolingual region where the promotion of "oral communication" in the context of a "bilingual education" has been singled out by the academic authorities as one of the major strands for the official teacher-training programmes run by the Department of Education (2011-12). This growing institutional interest ${ }^{2}$, however, does not seem to be accompanied by a deeper knowledge of the specific needs or actual level of communicative competence in the teaching and academic context. Therefore, we thought it necessary to carry out a global analysis of the current linguistic needs of students of English as a Foreign Language in Secondary Education $\left(1^{\text {st }}\right.$ year and $4^{\text {th }}$ year of ESO, and $2^{\text {nd }}$ year of Bachillerato) as well as the pedagogical and training needs of the teachers of English responsible for imparting these courses in our context.

Before focusing specifically on the information obtained from the teachers' questionnaire, we briefly describe the design and participants who took part in our global study.

(C) Servicio de Publicaciones. Universidad de Murcia. All rights reserved. IJES, vol. 14 (1), 2014, pp. 55-77 Print ISSN: 1578-7044; Online ISSN: 1989-6131 


\section{METHODS}

\subsection{Research design}

In order to perform our needs analysis, we carried out first a pilot study with the collaboration of 173 students and 7 teachers of English from a local secondary school. A total of 25 questions were included in each of the four individual questionnaires to be answered by $1^{\text {st }}$ year ESO, $4^{\text {th }}$ year ESO, $2^{\text {nd }}$ year Bachillerato students and their teachers. Some of these questions were common to all four groups so as to compare their answers, whereas others addressed issues specific to each individual group. All the questions fell into one of the following categories:

1. Methodological approaches to the teaching/learning of oral skills

2. The learning process and assessment of oral skills

3. Motivation and attitude towards EFL

4. Teaching policies and training needs in EFL

Our aim in the second stage of the project was to validate the initial results from the pilot study and to obtain a clearer picture of the situation in our local context. This goal implied the need to redesign and distribute the questionnaires to a larger representative sample. Thus, we asked for the voluntary cooperation of those teachers of English attending the annual meeting of Armonización ${ }^{3}$. In order to refine the representativeness of the final sample, we also set up a series of variables which might have an effect on the results of the survey, namely:

Variable 1: Type of school (State-run / State-subsidised / Private)

Variable 2: Location: 3 provinces in Aragón (Zaragoza / Huesca / Teruel)

Variable 3: Area (Urban / Rural)

Variable 4: Methodological approach (Bilingual (CLIL) / Monolingual (EFL))

Fifteen secondary schools were selected from the total number of volunteers, which covered the categories established as shown in Table 1.

In this paper we focus exclusively on the teachers' answers to this questionnaire and, particularly, on their attitudes, beliefs and expectations towards issues such as the implementation of the Common European Framework of Reference for Languages (CEFRL), the current practices in the teaching of oral skills, and the types of tests being devised for the assessment of Foreign Language oral skills. ${ }^{4}$ 


\begin{tabular}{|c|c|c|c|c|c|c|}
\hline & Province & Area & $\begin{array}{c}\text { Type of } \\
\text { school }\end{array}$ & $\begin{array}{l}\text { Methodological } \\
\text { approach }\end{array}$ & $\begin{array}{c}\text { No of } \\
\text { teachers }\end{array}$ & $\begin{array}{c}\text { No of } \\
\text { students }\end{array}$ \\
\hline $\begin{array}{l}\text { IES Pedro } \\
\text { de Luna (I) }\end{array}$ & Zaragoza & Urban & State-run & Bilingual & 8 & 127 \\
\hline $\begin{array}{l}\text { IES Pedro } \\
\text { de Luna (II) }\end{array}$ & Zaragoza & Urban & State-run & Monolingual & -- & 176 \\
\hline $\begin{array}{l}\text { IES } \\
\text { Miralbueno }\end{array}$ & Zaragoza & Urban & State-run & Monolingual & 5 & 66 \\
\hline $\begin{array}{l}\text { IES } \\
\text { Tiempos } \\
\text { Modernos }\end{array}$ & Zaragoza & Urban & State-run & $\begin{array}{l}\text { Bilingual } \\
\text { /Multilingual }^{5}\end{array}$ & 2 & 74 \\
\hline $\begin{array}{ll}\text { Col } & \text { Sta } \\
\text { María } & \text { del } \\
\text { Pilar } & \end{array}$ & Zaragoza & Urban & $\begin{array}{l}\text { State- } \\
\text { subsidised }\end{array}$ & Monolingual & 5 & 264 \\
\hline $\begin{array}{l}\text { Col. La } \\
\text { Salle-Gran } \\
\text { Vía }\end{array}$ & Zaragoza & Urban & $\begin{array}{l}\text { State- } \\
\text { subsidised }\end{array}$ & Monolingual & 4 & 192 \\
\hline $\begin{array}{l}\text { Col. } \\
\text { Británico de } \\
\text { Aragón }\end{array}$ & Zaragoza & Urban & Private & Bilingual & 2 & 75 \\
\hline $\begin{array}{l}\text { Liceo } \\
\text { Europa }\end{array}$ & Zaragoza & Urban & Private & Monolingual & 2 & 115 \\
\hline $\begin{array}{l}\text { IES Emilio } \\
\text { Jimeno }\end{array}$ & $\begin{array}{l}\text { Zaragoza } \\
\text { (Calatayud) }\end{array}$ & Rural & State-run & Monolingual & 6 & 204 \\
\hline $\begin{array}{l}\text { Col } \\
\text { Salesianos } \\
\text { Laviaga } \\
\text { Castillo }\end{array}$ & $\begin{array}{l}\text { Zaragoza } \\
\text { (La } \\
\text { Almunia) }\end{array}$ & Rural & $\begin{array}{l}\text { State- } \\
\text { subsidised }\end{array}$ & Monolingual & 2 & 40 \\
\hline $\begin{array}{l}\text { IES Lucas } \\
\text { Mallada }\end{array}$ & Huesca & Urban & State-run & Monolingual & 5 & 107 \\
\hline $\begin{array}{ll}\text { IES } & \text { La } \\
\text { Llitera } & \end{array}$ & $\begin{array}{l}\text { Huesca } \\
\text { (Tamarite) }\end{array}$ & Rural & State-run & Monolingual & 3 & 90 \\
\hline $\begin{array}{l}\text { IES Santa } \\
\text { Emerenciana }\end{array}$ & Teruel & Urban & State-run & Monolingual & 6 & 134 \\
\hline $\begin{array}{l}\text { IES } \\
\text { Segundo de } \\
\text { Chomón }\end{array}$ & Teruel & Urban & State-run & Monolingual & 6 & 187 \\
\hline $\begin{array}{ll}\text { Col. } & \text { Las } \\
\text { Viñas } & \\
\end{array}$ & Teruel & Urban & $\begin{array}{l}\text { State- } \\
\text { subsidised }\end{array}$ & Monolingual & 4 & 99 \\
\hline $\begin{array}{l}\text { IES } \\
\text { Salvador } \\
\text { Victoria }\end{array}$ & $\begin{array}{l}\text { Teruel } \\
\text { (Monreal } \\
\text { del Campo) }\end{array}$ & Rural & State-run & Monolingual & 3 & 60 \\
\hline TOTAL: 15 & $\begin{array}{l}\text { Zaragoza } \\
(9) \\
\text { Huesca (2) } \\
\text { Teruel (4) }\end{array}$ & $\begin{array}{l}\text { Urban } \\
(10) \\
\text { Rural (5) }\end{array}$ & $\begin{array}{l}\text { State-run } \\
(9) \\
\text { State- } \\
\text { subsidised } \\
(4) \\
\text { Private (2) }\end{array}$ & $\begin{array}{l}\text { Multi/Bilingual } \\
\text { (3) } \\
\text { Monolingual } \\
(12)\end{array}$ & 63 & 2,010 \\
\hline
\end{tabular}

Table 1. Sample of secondary schools participating in the study 


\subsection{Participants}

The teachers' questionnaire was distributed as an online survey (Survey Monkey Plus) ${ }^{6}$ in February 2012. The number of teachers that completed the final survey was 63: one third aged between 36 and 45 and another third between 46 and 55. While most of the teachers work at present in state-run high schools (69.8\%), the remaining $30.2 \%$ have a contract either in state-subsidised $(23.8 \%)$ or private schools $(6.3 \%)$.

The average respondent to our teacher survey was a female (76.7\%), older than 36 (73.3\%) and with a consolidated teaching experience of more than 11 years $(63.3 \%)$ working in a tenured job in a state-run high school (50\%) in an urban area.

The results show that most teachers $(78.3 \%)$ in the sample had obtained their university degrees more than 11 years ago and $41.7 \%$ had attended more than 30 courses to update their teaching methodologies or to expand their subject-related knowledge during that period. The credits awarded by attending these courses are necessary for promotion and this may to some extent account for these high results. However, most of them have permanent positions, which reveals a remarkable interest in furthering their education.

The sample of teachers in the survey was unevenly distributed geographically: $77.7 \%$ work in urban areas (capitals of provinces), whereas 22.2\% work in smaller towns in those three provinces. It may be worth pointing out here that the demographic distribution in Aragón is itself very uneven, with $50 \%$ of the total population of the region living in Zaragoza, the capital city.

When asked where they learned their English, the great majority (81\%) cited the University as the main provider of their language teaching, usually after a previous grounding at high school (76.2\%). A considerable number of teachers $(74.5 \%)$ report on their regular use and/or study of another foreign language, which in most cases (50\%) is French. Moreover, $26.6 \%$ of all teachers of English study or have studied two foreign languages. In that case, French is also an extremely popular option (87.5\%) - the region of Aragón borders France.

Apart from regular academic tuition, travelling and meeting people from different parts of the world seems to rank very high as a popular English-learning experience $(60.3 \%)$, followed by listening to songs and watching English-speaking TV channels (44.4\%). Notably, only $4.8 \%$ of all teachers of English who took the survey were native speakers. 


\section{ANALYSIS OF RESULTS}

\subsection{Methodological approaches to the teaching of oral skills}

\subsubsection{Resources and activities}

Regarding the time devoted to each of the four skills (speaking, listening, writing and reading) and what type of work was most commonly done in the class (Table 2) and outside the class (Table 3) results showed that teachers devote most class time to grammar and vocabulary and to reading, which tend also to be reinforced outside the classroom (bold type within the tables indicates which the most relevant items are). A lot of time is said to be devoted to listening in class, but this is not complemented by work done outside the class timetable in spite of the possibilities provided by household formats and devices (e.g. CDs, podcasts, mp3 players).

\section{(quite) a lot of time (very) little time}

$\begin{array}{lll}\text { Listening } & 74.6 \% & 25.4 \% \\ \text { Speaking } & 58.1 \% & 41.9 \% \\ \text { Reading } & 90.5 \% & 9.5 \% \\ \text { Writing } & 67.7 \% & 32.3 \% \\ \text { Grammar and vocabulary } & 96.8 \% & 3.2 \% \\ \text { Translation } & 23.3 \% & 76.7 \% \\ \text { Individual work } & 51.6 \% & 48.4 \% \\ \text { Groupwork } & 44.4 \% & 55.6 \% \\ \text { Projects } & 21.0 \% & 79.0 \% \\ \text { Completing the textbook } & 75.4 \% & 24.6 \% \\ \text { Work on the computer } & 16.1 \% & 83.9 \% \\ \text { Preparing exams } & 65.0 \% & 35.0 \%\end{array}$

Table 2. Time devoted in class to particular skills and language work

(quite) a lot of time (very) little time

$\begin{array}{lll}\text { Listening } & 5.3 \% & 94.7 \% \\ \text { Reading } & 72.6 \% & 27.4 \% \\ \text { Writing } & 73.0 \% & 27.0 \% \\ \text { Grammar and vocabulary } & 84.1 \% & 15.9 \% \\ \text { Translation } & 8.1 \% & 91.9 \% \\ \text { Individual work } & 93.7 \% & 6.3 \% \\ \text { Groupwork } & 8.1 \% & 91.9 \% \\ \text { Projects } & 14.5 \% & 85.5 \% \\ \text { Completing the textbook } & 77.8 \% & 22.2 \% \\ \text { Work on the computer } & 9.5 \% & 90.5 \% \\ \text { Preparing exams } & 58.1 \% & 41.9 \%\end{array}$

Table 3. Time devoted to particular skills and language work outside the classroom 
Somewhat less time is spent in the classroom on writing, which seems to be reinforced by individual work outside the classroom, probably due to lack of class time. Speaking is the least practiced skill in class; and it is difficult to assign tasks and activities to practice it further outside the classroom. This lack of emphasis on speaking may be a result of the reported students' reluctance to engage in communication and interaction activities (see Table 9), which would partially explain the teachers' perceived low assessment of the oral productive skills of their learners (see Figures 3 and 5). The activities in which students are engaged must offer them an incentive to seek solutions to their linguistic difficulties, as well as the means to do so (Swain, 2000: 100). In addition, teachers should find tasks which involve their students in collaborative dialogue, so that they could reflect on the target language forms at the time that they focus on meaning (Celce-Murcia and Olshtain, 2000; Ellis, 2003; Long, 1991; Long and Robinson, 1998; Nation and Newton, 2009; Thornbury, 2005). It should be born in mind that there are few opportunities outside the classroom for the students to practice their communication skills, which means that if not much attention is given to it within the classroom, it cannot be adequately developed. Other factors which may contribute to the scarcer work on productive skills may have to do with classroom management and to the feeling that "dense" syllabuses must be fully covered.

There is very little interest among teachers in carrying out translation exercises. It is interesting to note that many teachers consider this an activity to be avoided within the prevailing communicative approach, as it tends to be associated with historical and not particularly successful teaching methods.

According to the teachers' answers, computers are scarcely used in their classes and neither are tasks to be done on the computer regularly assigned as reinforcement outside the class. This idea seems to be inconsistent with the popularity of new technologies among a generation of students who are already "digital natives". It does not reflect, either, the great efforts and investment made by the local government in introducing ICTs in primary and secondary schools and the number of teacher training programmes on their use.

Various internet resources are used during the lessons and out of school, although by no means by all secondary school teachers (see Table 4). Our figures reveal a greater use of ICTs on the part of private and state-subsidised school teachers (with the exception of the interactive board, which is used by $70 \%$ of state school respondents). Films and YouTube videos with subtitles are reported to be used in class by $39 \%$ of respondents, and a similar percentage reported encouraging their use also outside the classroom. It is worth pointing out that international social networks, videogames, and other devices are not popular at all among the sample of teachers surveyed (in several cases the reason alluded to was that they do not know how to use them). The results of the survey make it clear that teachers have been making a great effort but some of them still have problems in having access or keeping up 
with the more recent devices (i.e. IWB, Tablets) or educational genres ("serious" videogames $)^{7}$.

These data can be compared with the results of a national study recently conducted by the Confederación Española de Centros de Enseñanza (2012), which concludes that only $40 \%$ of primary and secondary school teachers use ICTs regularly in the classroom, the reason for this being attributed mainly to their lack of training. When comparing the use of ICTs in schools in capital cities and smaller towns, the overall results point to a lesser use in smaller towns, both in and outside the class, although there seems to be an increasing tendency in the latter towards "blended learning"; that is, to reinforce class contents outside the classroom with language course materials, mainly those offered on CDs (34\%).

\begin{tabular}{|c|c|c|c|c|c|}
\hline & $\begin{array}{l}\text { Yes, in and } \\
\text { outside the } \\
\text { classroom }\end{array}$ & $\begin{array}{l}\text { Only in the } \\
\text { classroom }\end{array}$ & $\begin{array}{l}\text { Only outside } \\
\text { the } \\
\text { classroom, as } \\
\text { a } \\
\text { complement }\end{array}$ & $\begin{array}{l}\text { I do not use } \\
\text { them, nor do } \\
\text { I encourage } \\
\text { their use }\end{array}$ & $\begin{array}{l}\text { I can't use } \\
\text { them }\end{array}$ \\
\hline Computer or tablet & $28 \%$ & $30 \%$ & $36 \%$ & $5 \%$ & $2 \%$ \\
\hline Interactive board & $5 \%$ & $63 \%$ & $4 \%$ & $11 \%$ & $18 \%$ \\
\hline $\begin{array}{ll}\text { TDT, films and } \\
\text { videos (series, You } \\
\text { Tube) in their } \\
\text { original version (no } \\
\text { subtitles) }\end{array}$ & $22 \%$ & $35 \%$ & $35 \%$ & $8 \%$ & $0 \%$ \\
\hline $\begin{array}{lrr}\text { TDT, films } & \text { and } \\
\text { videos (series, You } \\
\text { Tube) in their } \\
\text { original } \\
\text { (subtitled) }\end{array}$ & $35 \%$ & $39 \%$ & $24 \%$ & $2 \%$ & $0 \%$ \\
\hline $\begin{array}{l}\text { Language courses } \\
\text { (CD) }\end{array}$ & $11 \%$ & $16 \%$ & $36 \%$ & $34 \%$ & $4 \%$ \\
\hline $\begin{array}{l}\text { Internet resources } \\
\text { (web pages, online } \\
\text { labs, etc) }\end{array}$ & $42 \%$ & $17 \%$ & $33 \%$ & $7 \%$ & $2 \%$ \\
\hline Video games & $0 \%$ & $9 \%$ & $28 \%$ & $43 \%$ & $21 \%$ \\
\hline $\begin{array}{lr}\begin{array}{l}\text { International } \\
\text { networks } \\
\text { skype, etc) }\end{array} & \text { (chats, } \\
\end{array}$ & $5 \%$ & $2 \%$ & $46 \%$ & $39 \%$ & $8 \%$ \\
\hline $\begin{array}{l}\text { Other tools (iPod, } \\
\text { iPad, iPhone, etc) }\end{array}$ & $7 \%$ & $2 \%$ & $30 \%$ & $39 \%$ & $23 \%$ \\
\hline
\end{tabular}

Table 4. Teachers' use of ICTs in the EFL classroom

There is, in general, a perceived need to guarantee sufficient teacher training in the use of programs and devices related to new technologies. We should not underestimate, however, 
the greater importance of learning "how" to exploit their pedagogical potential for second language learning in or outside the classroom. Teaching should be driven by the pedagogy and supported by the technology; or, in Jones' (1986) words, "it's not so much the program, more what you do with it".

The increasing number of resources for the foreign language classroom should be more efficiently exploited, as they may promote learners' autonomy in language learning (Benson \& Voller, 1997). These resources may not only promote self-access and self-study but also address particular learning styles and learners' responsibility with their own learning. They represent a considerable shift in the teaching-learning process and could motivate and engage students to practice English, even outside the classroom. Students in Secondary Education, active participants in the learning process, have at their disposal a wide range of materials that can make that process more engaging and meaningful. A good example of effective Internet learning applied to the learning of EFL is the use of educational games, treasure hunts, webtasks or more complex webquests, where students have to get involved in a process of interactive discovery to complete the tasks instead of merely receiving information from a website (Salaberry, 2001; Pérez Torres, 2007; Tomlinson, 2011). Further advantages of these activities are that they can promote extensive reading, collaborative work -by stimulating interaction in group activities- and they may be helpful in dealing with crosscurricular aspects in the foreign language classroom (of a great interest in CLIL pedagogies).

Oral skills being the focus of interest of this research, the questionnaire could not overlook the teaching resources used.

Almost always or often A few times or hardly ever

$\begin{array}{lll}\text { Use the textbook activities } & 76.2 \% & 23.8 \% \\ \text { Use internet resources } & 58.1 \% & 41.9 \% \\ \text { Adapt internet resources } & 46.0 \% & 54.0 \% \\ \text { Create my own materials } & 38.7 \% & 61.3 \% \\ \text { Use the school materials } & 46.8 \% & 53.2 \% \\ \text { Work alone } & 71.0 \% & 29.0 \% \\ \text { Work with other teachers of the subject } & 35.5 \% & 64.5 \% \\ \text { Work with teachers of other subjects } & 3.3 \% & 96.7 \%\end{array}$

Table 5. Resources used for the teaching of oral skills

As Table 5 shows, teachers still have a preference for individual work (71\%) using the textbook materials (76.2\%); to a lesser extent they use "raw" internet resources $(58.1 \%)$ or adapt them $(46 \%)$ but are not too keen on creating their own materials $(38.7 \%)$. As for curricular integration, results showed that they do not often collaborate with teachers of the same subject $(35.5 \%)$ whereas team-teaching with teachers of other subjects, which could 
result in better learning results in EFL as well as in English-medium instruction, is almost negligible (3.3\%) in all types of schools.

We now focus on the type of activities most commonly done by teachers in class, particularly in relation to oral skills (Table 6). What teachers reported doing most frequently in class to foster communication is ask students questions and make them listen to audio and video files. It is interesting to see that when oral practice is done in class, students do tend to work in pairs or small groups. This implies that although teachers seem to promote an IRF (Initiation, Response, Feedback) interaction pattern in class (Sinclair and Coulthard, 1975) by means of questions and answers and whole group speaking, which leads to rather teacherfronted classes, they also offer opportunities for their students to initiate and negotiate turns, to introduce and change topics, and to practise other important conversational strategies by means of pair and small group work, ultimately enhancing their discursive and strategic competence.

\section{(Very) commonly Not (very) practised}

$\begin{array}{lll}\text { Audio and video listening } & 82.5 \% & 17.5 \% \\ \text { Oral presentations } & 52.5 \% & 47.5 \% \\ \text { Debates / Discussions } & 29.5 \% & 70.5 \% \\ \text { Role plays } & 45.2 \% & 54.8 \% \\ \text { Asking questions to students individually } & 87.3 \% & 12.7 \% \\ \text { Pair or small group work } & 71.0 \% & 29.0 \% \\ \text { Whole group speaking } & 66.1 \% & 33.9 \% \\ \text { Projects } & 19.4 \% & 80.6 \% \\ \text { Work on the computer } & 11.7 \% & 88.3 \%\end{array}$

Table 6. Types of activities reported by teachers to be practised in class

According to the respondents, discussions are not commonly set up in the classroom, neither are projects, which could contribute to developing students' conversational and negotiation skills in the L2. This may be especially relevant in the upper levels since it is important to settle achievement goals appropriate to each language level and to use techniques and exercises suitable to the learner's age and maturity. Role plays were reported to be used in the classroom by surprisingly few teachers, considering that students can thus practise their sociolinguistic competence, trying to make use of the language in an appropriate way given the particular situation and participants in the oral exchange. It can also lead teachers to make students focus on transactional rather than interactional (social) communication encounters. 
Opinions are divided with regard to the practice of oral presentation skills. Some teachers consider this an appropriate activity, as monologic rather than dialogic discourse is practised and the focus tends to be on accuracy. A commonly stated problem with presentations is the amount of time that they take and also the need to encourage the participation of the listening classmates.

When answers from teachers working at bilingual and at monolingual schools are compared, it transpires that the activities done are very similar and so are the teachers' preferences. They tend to focus mainly on questions and answers, whole group work, and listening comprehension and they hardly ever do projects, debates, and role plays. These teaching practices make it clear that oral skills need to be further fostered in the classroom.

\subsubsection{Classroom discourse interaction}

Teacher talk is an important source of comprehensible input to which learners are exposed and it therefore has a relevant role in the learners' development of oral skills (Krashen, 1985, 2003). Teachers were consequently asked for their views regarding the use of the L2 in the classroom. In particular, they were asked what percentage of the classroom interaction took place in English in their classes; a further distinction was made between Teacher and Student Talking Time:

\section{Teacher-student $92.1 \%$ \\ Most interaction in English Most interaction in Spanish \\ Student-teacher $45.7 \% \quad 54.3 \%$}

Table 7. Amount of teacher talk and student talk in the L2

Whereas teachers reported that they use English most of the time in their classes, students' talking time seems to be low. Even if teachers' answers indicate that the use of English by students increases as they move to upper levels, and is higher in the case of students attending bilingual schools ( $57.7 \%$ vs $42.6 \%)$, it is still comparatively low. Even though these are teachers' perceptions, not corroborated by classroom observation, they were contrasted with students' answers to the same question. Such comparison showed similar findings (Hornero et al., 2013), which strengthens the validity of their answers.

Teachers acknowledge the need for students to adopt English as their language of communication in class when they report the importance of pushing students to use the L2 (66.7\%) and fostering their fluency $(90.5 \%)$. Figure 1 below also shows that teachers are more keen on adapting their teaching materials than on mainly using a textbook, and that fluency is encouraged over accuracy in oral communication. 
Apart from the necessary increase in the total input students get in the foreign language (in and outside the classroom), teachers' perceptions seem to be in line with Swain's (2005) output hypothesis, according to which not only is comprehensible input required for students to acquire communicative competence, but also opportunities to use the language.

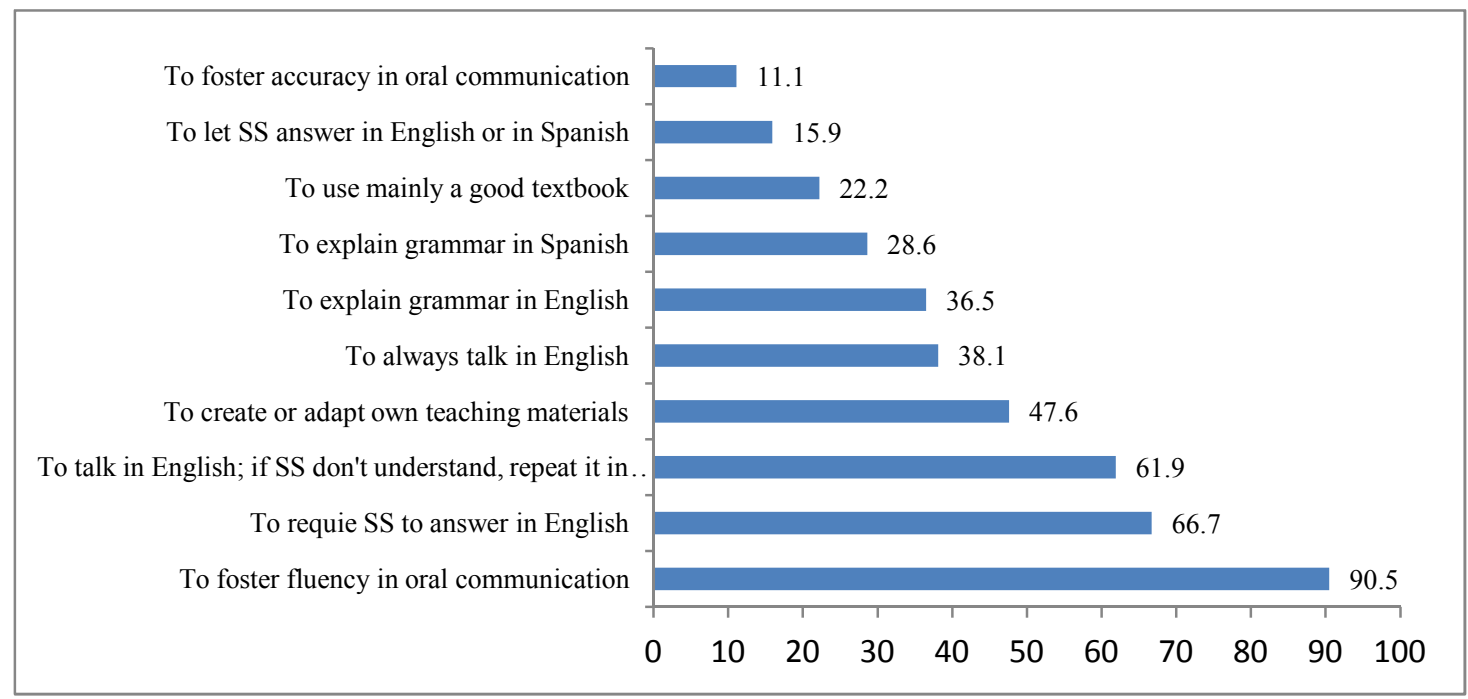

Figure 1. Factors to promote student talk in the L2

\subsection{The students' learning process and assessment of oral skills}

Teachers were also asked to rank the difficulty students find with different types of listening comprehension texts as well as when doing listening comprehension practice. Teachers observe that their students have particular difficulty with listening to authentic texts coming from sources other than the teaching materials. The only texts that their students do not seem to have great difficulty with are the graded files in the textbook, because these tend not to include distinctive features of spontaneous oral discourse. The percentages of respondents describing them as "very easy" and "easy" were considerably higher in bilingual schools, which is in line with the better oral performance of their students reported below.

The respondents perceived that the most common problems experienced by students when doing listening comprehension practice are the length (77.4\%) and the pace of the text $(64.5 \%)$, which has to be slow and clear, as is usually the case with graded teaching materials. Students also need to listen to the text more than once $(77.8 \%)$ for it to be understood. Paradoxically, and worth pointing out here, is the CEFRL recommendation of the use of authentic material, specially at higher levels, provided the tasks are well-designed and help the learner to a better understanding of the text (Harmer 2000). Finally, because students can find it difficult to express what they have listened to $(65.1 \%)$, it is important that the skill 
is practiced in isolation so that teachers can actually check their students' comprehension skills. Thus, exposing students to this input may also strengthen their speaking and interactional skills (Rost, 1994, 2005).

Some of the questions were intended to get teachers to assess their students' general performance in English. More specifically, we enquired whether they believe students in the $4^{\text {th }}$ year ESO reach the A2 level of the CEFRL, and whether students in $2^{\text {nd }}$ year Bachillerato reach the B1 level of the CEFRL. In both cases, teachers reported better overall assessment of their students' written than of their oral competence:

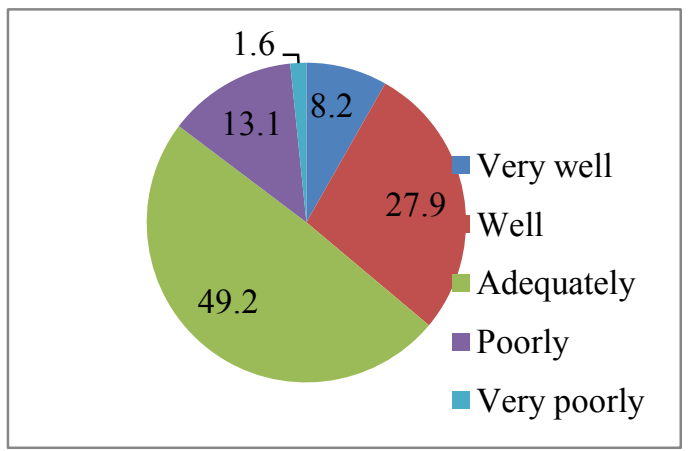

Figure 2. Teachers' view on whether SS reach $\mathbf{A 2}$ level (written skills)

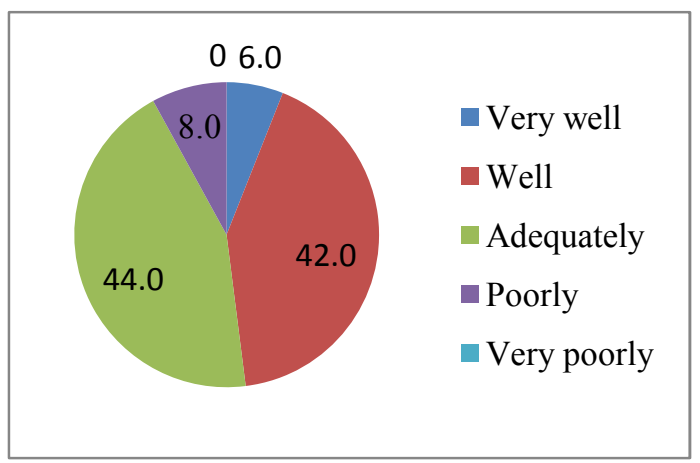

Figure 4. Teachers' perceptions on SS's B1 Figure 5. Teachers' view on whether SS reach level (written skills)

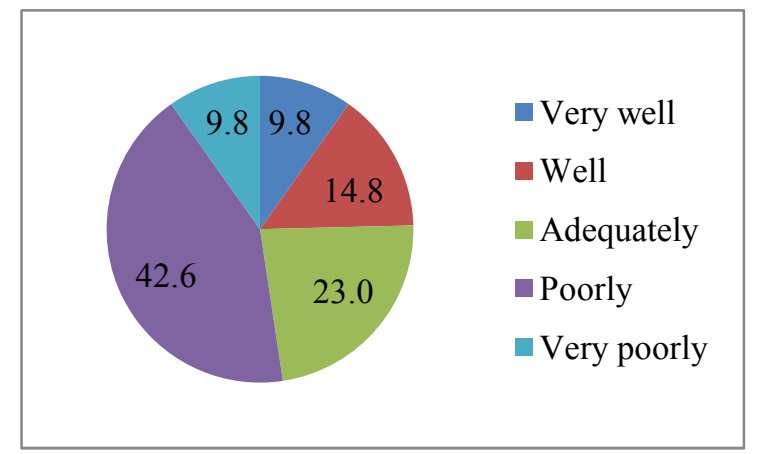

Figure 3. Teachers' view on whether SS reach A2 level (oral skills)

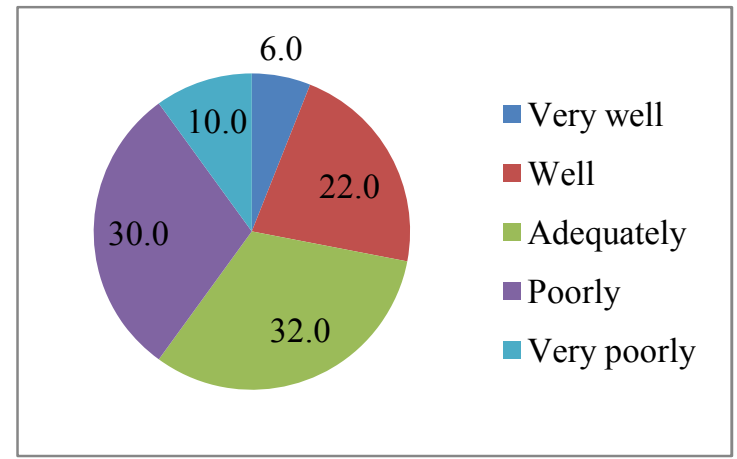

B1 level (oral skills)

According to the teachers' views, a progression can be observed from A2 to B1 levels in terms of the extent to which their students reach the corresponding level. In addition, it seems that answers are more homogeneous in the case of written skills and there is more dispersion in the case of oral skills. This means that students in the same level may achieve more similar written skills but their speaking performance is much more diverse, a few of them communicating "very poorly" or "very well" according to their teachers, some of them doing reasonably "well" and many communicating "poorly" in English. 
It is interesting to see that in bilingual schools teachers consistently believe students' oral performance to be better than their written performance. This may be a result of the higher number of English-medium instruction hours, which entails far greater exposure to the foreign language and the subsequent improvement of the students' oral skills in these schools. Generally, then, the answers of teachers working at bilingual schools and also at private and state-subsidised schools are more positive than those at monolingual schools and state schools.

Teachers also ranked, based on their perceptions, their students' achievement of particular oral subskills at different levels of their secondary education. The oral subskills in Table 8 are meant to be a representative sample, not exhaustive, of the contents that should be included in the teaching and assessment of second language speaking; they fall mainly within the categories of language competence and strategic capacity, following the framework for the speaking construct suggested by Fulcher (2003: 48).

\begin{tabular}{|c|c|c|c|c|}
\hline \multicolumn{5}{|l|}{1 st year $E S O$} \\
\hline & $\begin{array}{l}\text { Very } \\
\text { good }\end{array}$ & Good & Fair & Poor \\
\hline comprehension & $14.6 \%$ & $65.9 \%$ & $19.5 \%$ & $0.0 \%$ \\
\hline use of vocabulary & $19.5 \%$ & $36.6 \%$ & $39.0 \%$ & $4.9 \%$ \\
\hline pronunciation & $7.3 \%$ & $26.8 \%$ & $58.5 \%$ & $7.3 \%$ \\
\hline fluency & $2.4 \%$ & $22.0 \%$ & $58.5 \%$ & $17.1 \%$ \\
\hline grammatical accuracy & $4.9 \%$ & $41.5 \%$ & $46.3 \%$ & $7.3 \%$ \\
\hline interaction & $12.2 \%$ & $46.3 \%$ & $29.3 \%$ & $12.2 \%$ \\
\hline \multicolumn{5}{|l|}{ 4th year $E S O$} \\
\hline & $\begin{array}{l}\text { Very } \\
\text { good }\end{array}$ & Good & Fair & Poor \\
\hline comprehension & $23.8 \%$ & $64.3 \%$ & $11.9 \%$ & $0.0 \%$ \\
\hline use of vocabulary & $7.1 \%$ & $54.8 \%$ & $35.7 \%$ & $2.4 \%$ \\
\hline pronunciation & $0.0 \%$ & $42.9 \%$ & $52.4 \%$ & $4.8 \%$ \\
\hline fluency & $4.8 \%$ & $28.6 \%$ & $61.9 \%$ & $4.8 \%$ \\
\hline grammatical accuracy & $0.0 \%$ & $52.4 \%$ & $45.2 \%$ & $2.4 \%$ \\
\hline interaction & $7.1 \%$ & $40.5 \%$ & $52.4 \%$ & $0.0 \%$ \\
\hline \multicolumn{5}{|l|}{ 2nd year Bachillerato } \\
\hline & $\begin{array}{l}\text { Very } \\
\text { good }\end{array}$ & Good & Fair & Poor \\
\hline comprehension & $39.5 \%$ & $55.3 \%$ & $5.3 \%$ & $0.0 \%$ \\
\hline use of vocabulary & $21.6 \%$ & $48.6 \%$ & $29.7 \%$ & $0.0 \%$ \\
\hline pronunciation & $8.1 \%$ & $54.1 \%$ & $35.1 \%$ & $2.7 \%$ \\
\hline fluency & $8.1 \%$ & $35.1 \%$ & $51.4 \%$ & $5.4 \%$ \\
\hline grammatical accuracy & $10.8 \%$ & $70.3 \%$ & $18.9 \%$ & $0.0 \%$ \\
\hline interaction & $18.9 \%$ & $37.8 \%$ & $32.4 \%$ & $10.8 \%$ \\
\hline
\end{tabular}


Table 8. Teachers' assessment of their students' interaction subskills

Most teachers reported that their students are not very good at fluency and at pronunciation, although they seem to improve as they reach higher levels, as shown by the higher percentages of "good" and "very good" answers. What improves most is the students' grammatical accuracy, for which an overall $70.3 \%$ of answers indicate a good level when students leave high school.

Teachers were also asked about their current practices in the assessment of their students' oral skills in each of the three levels under analysis. The data show that in $1^{\text {st }}$ year of Secondary Education for $80.5 \%$ of the teachers oral skills represent up to $25 \%$ and not more of the total grade in the assessment of English. In bilingual schools the percentage is lower (66.7\%), indicating a higher degree of security in these skills. Monolingual schools, on the other hand, show the highest percentage in this section $(84.4 \%)$, showing therefore the lowest level of confidence of all. A greater degree of confidence is shown in state-subsidized and private schools $(72.7 \%)$.

In $4^{\text {th }}$ year of Secondary Education for $69.8 \%$ of the teachers oral skills represent up to $25 \%$ and not more of the total grade in the assessment of English, which can be interpreted as an improvement in the students' oral practice, reflected in a greater importance or visibility in the total grade for English at this stage (students are aged 15-16 then). In bilingual schools the figures expand to $85.7 \%$, revealing that the practice of oral skills for students of $4^{\text {th }}$ year may have decreased in comparison with the results shown for $1^{\text {st }}$ year of Secondary Education.

When comparing state-run to private and state-subsidised schools, the latter showed the highest degree of confidence as they obtain $50 \%$, whereas the former show a much higher percentage: $79.3 \%$.

In $2^{\text {nd }}$ year of Post-Secondary Education, for $73.2 \%$ of the teachers oral skills represent up to $25 \%$ and not more of the total grade in the assessment of English, a slight contraction of the figures shown in $4^{\text {th }}$ year of Secondary Education. The reason may be that the number of lessons per week decreases from 4 to 3 , a cut involving less time invested in the practice of oral skills, as a good number of teachers point out. In bilingual schools the percentage of teachers who believe oral skills need to be assigned up to $25 \%$ of their students' overall grade in English rises to $77.8 \%$, something that again leads us to wonder why teachers tend to give progressively less importance to the assessment of oral skills as their students grow up.

How do teachers in Aragón assess oral skills? Answers indicated there are three main types of testing in ESO (Secondary Education), the most widely applied being a listening comprehension, followed by a student's monologue for a few minutes on a topic, photograph or prompt supplied by the teacher. The third choice consists of a dialogue with the teacher. In Bachillerato (post-obligatory Secondary Education), both the listening comprehension test and the student's monologue on a topic or photograph supplied by the teacher were the most 
common assessment tasks, followed by a dialogue with the teacher. There was general homogeneity in the choice of testing methods of oral skills, regardless of the type of school, although bilingual centres use other methods (e.g. oral presentations) in addition to the most widespread ones.

Although the possibility of including a test of the oral skills in the University Entrance Examination of foreign languages has been pending for years, and this has probably had a strong influence on the teaching methodology in Secondary Education, a firm decision has not yet been made regarding the new Reválida exams (LOMCE). This type of Examination, according to a high percentage of the respondents in Aragón (62.9\%), should already make room for the test of oral skills ${ }^{8}$. The figure increases in the answers given by teachers at bilingual schools (75\%) and where, interestingly enough, no negative answers are given. Answers are more evenly distributed in monolingual schools: $60 \%$ are for the inclusion of testing the oral skills, $14 \%$ are against and $26 \%$ (a very similar percentage to that found in the global data and also in bilingual schools) give a range of open ended answers. It is worth pointing out that a majority of teachers in state-subsidised and private schools are in favour of including an oral test $(88.9 \%)$. This contrasts sharply with teachers' answers in state-run schools, where only $52.3 \%$ are in agreement.

Apart from other socio-economic factors, these answers reflect the concerns of teachers in post-compulsory Secondary Education (Bachillerato), who believe there should be more teaching hours per week as well as a lower number of students per class. At present, $2^{\text {nd }}$ year of Bachillerato only offers three English lessons per week, which is considered insufficient by a good number of teachers.

Finally, they all express their worries about the practical organization, the expense involved and the successful outcome of an oral test aimed at more than 4,000 students in June (Aragón), which would require the participation of a large number of examiners. This should remind us that administrative arrangements and the physical conditions in which the test takes place may have an impact on performances and scores on this test, as it has been repeatedly proved (see for instance Fulcher, 2003).

We were also interested in retrieving teachers' opinions on what percentage of the total grade should correspond to the oral skills in the foreign languages paper of the Schoolleaving or University Entrance Examination and what type of tasks it should contain. A good $66 \%$ of the respondents would set a maximum of $25 \%(60 \%$ in the case of bilingual schools and $67.6 \%$ in monolingual schools). One of the most interesting findings is the sharp difference between the responses from state-run schools $(78.8 \%$ in favour of the $25 \%$ maximum mark for oral skills) and state-subsidised and private schools (35.7\%). This suggests a much higher degree of confidence in the oral performance of students in the latter case, since $64.3 \%$ would be willing to give the oral test more than $25 \%$ of the total grade. 
The answers regarding the type of test they would consider appropriate reflect their own regular testing of oral skills, listening comprehension being the most popular option, followed by a student's monologue on a topic or photograph supplied by the teacher and a third choice consisting of a dialogue with the teacher.

\subsection{The students' learning process and assessment of oral skills}

Affective and attitudinal factors have an important influence on learning in general and on the development of oral skills in particular. It is now generally accepted that affect and cognition are part of the learner's whole-person development (Arnold, 2011). Therefore, the questionnaire also sought to gather information on the importance that teachers believe such factors have on their students' performance, as well as on other factors which may have an influence in the current teaching and learning of oral skills. Teachers were given some statements and had to indicate the extent to which they agreed with them.

\begin{tabular}{|l|l|l|}
\cline { 2 - 3 } \multicolumn{1}{l|}{} & $\begin{array}{l}\text { I totally /quite } \\
\text { agree }\end{array}$ & $\begin{array}{l}\text { I totally /quite } \\
\text { disagree }\end{array}$ \\
\hline Students are reluctant to speak in English & $73.0 \%$ & $27.0 \%$ \\
\hline $\begin{array}{l}\text { Students' motivation improves in higher levels of } \\
\text { Secondary Education }\end{array}$ & $36.5 \%$ & $63.5 \%$ \\
\hline $\begin{array}{l}\text { The attitude towards those who participate in class is } \\
\text { neutral or positive }\end{array}$ & $79.4 \%$ & $20.6 \%$ \\
\hline $\begin{array}{l}\text { The general level of oral English has improved in recent } \\
\text { years }\end{array}$ & $54.0 \%$ & $46.0 \%$ \\
\hline $\begin{array}{l}\text { If more time is devoted to oral skills, written skills are } \\
\text { negatively affected }\end{array}$ & $19.0 \%$ & $81.0 \%$ \\
\hline Students' general feeling about English is positive & $52.4 \%$ & $47.6 \%$ \\
\hline $\begin{array}{l}\text { Most of my students are not going to use the English } \\
\text { language in the future }\end{array}$ & $9.8 \%$ & $90.2 \%$ \\
\hline
\end{tabular}

Table 9. Teachers' evaluation of the role of affective and attitudinal factors in SS's learning of oral skills

Results showed that one of the main problems in the teaching and learning of oral skills may be that students are, according to the teachers, reluctant to speak in English in the classroom. This may lead teachers not to focus on this skill as much as would probably be necessary. On the other hand, many teachers feel the need to practice oral activities as they do not believe that this will be at the expense of written skills and because they are aware their students will need such skills in their future. Furthermore, as indicated above, they are aware of the general poor performance of their students and the need to promote student talking time. However, they need to find ways to overcome the students' apparent unwillingness to carry out communication tasks or activities. 
According to teachers (see Figure 6), the two most important factors in trying to overcome students' reluctance to speak in class and make students practice productive oral skills are to create a positive atmosphere so that students feel at ease $(85.7 \%)$ and to focus on topics of interest to them $(84.1 \%)^{9}$. Half of the teachers also considered it important that students know the vocabulary that is needed (58.7\%) and that they feel they are not being assessed (46.0\%) -the stress involved may influence learners' performance negatively. Moreover, they think that there are some factors which do not contribute to making students willing to practice productive oral skills: correcting their mistakes, as this will possibly entail their interruption, marking their performance, or all those aspects which make them perceive the task as less meaningful (Arnold, 2011; Davis, 2009).

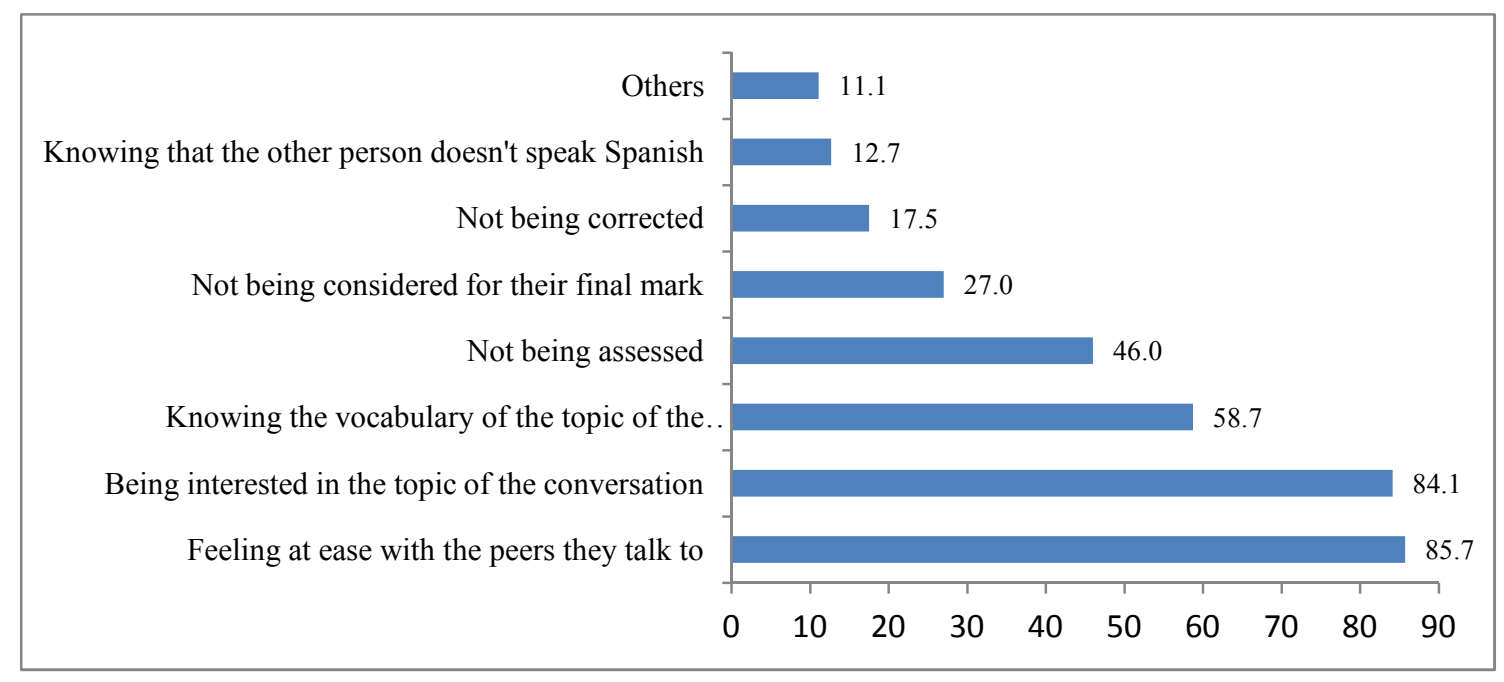

Figure 6. Teachers' views on factors which can contribute to making SS willing to participate in oral activities

\subsection{Teaching policies and training needs in EFL}

There seems to be agreement among respondents that the time devoted to EFL teaching is too limited to achieve a good L2 level (50\%), although they feel that their students must make a greater effort to achieve that goal (31.7\%). Curiously enough, teachers from bilingual and monolingual schools as well as those in urban or rural areas coincide in their diagnosis on these two factors. The third factor regarded as necessary in the improvement of the oral skills in English is a stay in a country where the language is used.

When asked to determine the extent to which some factors may contribute to improving their pupils' oral skills, teachers generally agree (84\%) that reducing the number of pupils in the English language classroom is absolutely necessary, as well as the obligatory presence of the assessment of the four skills in language learning (58.1\%). This is consistent with the 
widespread belief that what is bound to be assessed needs to be seriously taught, learnt, and practiced beforehand.

Of a series of measures introduced in high schools to improve students' oral performance, Aragonese teachers point to three as being particularly efficient: having smaller groups of students in each class $(77.4 \%)$, travelling abroad and getting the students involved in exchanges (70.5\%) and having English-speaking assistant teachers (66.1\%). The results obtained in monolingual schools coincide with the regional results. Bilingual schools, however, consider travelling abroad and getting the students involved in exchanges a priority $(91.7 \%)$, followed by having smaller groups of students in class, as well as promoting CLIL methodologies $(83.3 \%$ ) - a factor that goes almost unnoticed in monolingual schools - and having English-speaking assistant teachers (75\%).

This research also reflects our concern with teachers' training needs. A good $30 \%$ of teachers regard as "very helpful" attending courses that have a bearing on the English language. We thought this would be a good opportunity to ask teachers about the training they miss or feel as necessary because that would unquestionably have a positive impact on their English classes. When asked in what way they think that training could improve teachers' strategies in the teaching of oral communication in English, their main answers point to a need of training in teaching methodology (70.5\%), ICTs $(60.7 \%)$, and didactics (especially how to cope with mixed ability classes) (57.4\%).

In particular, a large share of teachers $(76.2 \%)$ claim to be willing to retrain in English courses, and the majority (98.2\%) in courses designed for and applicable to teaching. As we argued above, the average number of training courses taken by these professionals is very high. Our data confirm that teachers are willing to continue their training in those aspects related to their needs irrespective of their consolidated teaching experience. Therefore, it is clear from the findings that a major area of intervention is that of teacher training and lifelong learning.

\section{CONCLUSIONS}

The present paper has sought to provide an overall view of the teachers' attitudes, beliefs and expectations regarding EFL in general and the teaching and learning of oral skills in particular in a local Spanish-based context (Aragón). The increasing demands, among them the assessment of oral skills in the future School-leaving exams for foreign languages, are raising the general concern about oral competence in the teaching learning process. This study makes public the voice and opinions of teachers working in different educational environments but considered overall to be a representative sample of the region. Some of the conclusions drawn from the survey are summarized below, together with a number of recommendations aimed at raising awareness of the students' current level of oral 
competence and ways of improving it. In light of the findings we assess the implications of the study and suggest areas for future pedagogical intervention.

First, we found that grammar, vocabulary and reading tasks related to a textbook continue to be the most commonly practiced activities both inside and outside the classroom. Although increasingly worked upon in class, listening exercises should be, however, reinforced by work done more extensively outside the class, with the aid of newly introduced authentic materials which can increase the total exposure time and raise the interest of the students (i.e. podcasts, TV series).

The survey further shows that, despite the considerable investment made by the local government in introducing ICTs in primary and secondary schools, computers are scarcely used in EFL classes and neither are tasks to be done on the computer regularly assigned as reinforcement outside the class. The overall results also point to an even lesser use of computers in smaller towns. However, the increasing number, quality and interactivity of these resources makes them worth using in and outside the classroom, since they may recreate authentic contexts, give meaning to tasks as suggested by the literature (Ellis 2003; Estaire \& Zanón, 1994; Littlewood, 2004) and motivate students to practice their English. The use of educational games, webtasks and quests, classroom blogs and wikis have been proved to promote collaborative work and may be helpful too in dealing with cross-curricular aspects in the foreign language classroom (particularly interesting in CLIL pedagogies). The fact that these activities tend to focus on meaning rather than on form and require the use of language to carry out a task, promote a more effective EFL learning (Harmer, 1982; Long, 1991; Long and Robinson, 1998).

Although the responding teachers practise different conversational strategies in the classroom, they admitted that speaking was the least practiced skill in class, which may be due in great part to the students' reluctance to engage in communication and interaction activities. The incorporation of projects in the teaching/learning process would surely encourage cooperative learning and would develop students' conversational and negotiation skills in the L2, making them feel more at ease. Project-based learning functions as a bridge between using English in class and engaging students in investigation of authentic problems or tasks beyond the classroom (Blumenfeld, 1991; Fried-Booth, 1997). This could help overcome students' reluctance to speak by providing a reason to communicate, focusing on topics of their interest and creating a positive atmosphere.

Teachers report better overall results in their students' written than in their oral competence. Moreover, the percentage of very poor performance in oral skills increases in inverse proportion to good performance in written skills in both ESO and Bachillerato (students' grammatical accuracy seems to be what improves most). Our only advice here to balance students' competence in oral and written skills would be to ask for the 
implementation of a sensible method to assess the oral skills, particularly in the future type of School-leaving exams, along the lines of those proposed by our respondents.

Finally, of a series of measures introduced in high schools to improve students' oral performance, Aragonese teachers cite three as particularly efficient: having smaller groups of students in each class ("desdobles"), promoting CLIL methodologies (a recurrent goal in bilingual schools) and encouraging students to travel abroad or get involved in language immersion courses (motivation). We find their answers sensible and convincing; these measures have proved fruitful in the past and should be noted despite the current situation of increasing budget cuts.

\section{NOTES}

1. This research has been carried out within the framework of the Project FFI2012-37346 and Proyecto de Cooperación entre Departamentos Universitarios y Departamentos de Institutos de Educación Secundaria. Diputación General de Aragón (245-188).

2. See, for instance, La competencia en comunicación lingüistica en el aula: Experiencias en Aragón (2013).

3. In this meeting the university lecturer in charge of the design of the University entrance exam of English gathers with teachers of $2^{\text {nd }}$ year Bachillerato and deal with various aspects of the exam (results, difficulties found, how to overcome them, design, etc.).

4. See Hornero et al. (2013) and Mur et al. (2014) for an analysis of the students' answers to this questionnaire.

5. "Multilingual" schools run a sort of integrated approach to language teaching whereby alternating languages are used as a means of instruction in specific subjects and in consecutive years. For practical purposes, they have been categorized as "bilingual" in our study.

6. The Teachers' questionnaire contains 27 questions and has been deemed too long to be added as an Appendix. However, it can be accessed at: http://www.surveymonkey.com/s/BPFVY9X

7. Examples of the use of games and simulations for language teaching in Virtual Learning Environments can be found in $\langle e$-Adventure $\rangle$

http://catedu.es/webcatedu/index.php?option=com content\&view=article\&id=353\&Itemid=95.

8. To this day, the foreign language test does not take account of the oral skills. It tests the reading comprehension of a text, some grammar points in the form of rephrasing "so that the meaning should be the same as that of the sentence above" and a written composition. See Herrera (1999) for an analysis questioning the validity of this design as a discriminating tool.

9. The concern for the group dynamics is very important in language learning, given the interactive nature of language classes (Arnold, 2011). Dörnyei and Murphy (2003) suggest keeping in mind the TEAM acronym: Together Everyone Achieves More. On the other hand, teacher confirmation (Ellis, 2000:265) may play a valuable role in the creation of a positive atmosphere. 


\section{REFERENCES}

Arnold, J. (2011). Attention to affect in language learning. Anglistik. International Journal of English Studies, 22(1), 1-22.

Benson, P. \& Voller, P. (1997). Introduction: Autonomy and independence in language learning. In P. Benson \& P. Voller (Eds.). Autonomy and Independence in Language Learning, (pp. 1-12). London / New York: Longman.

Blumenfeld, P., Soloway, E., Marx, R., Krajcik, J., Guzdial, M. \& Palincsar, A. (1991). Motivating project-based learning: Sustaining the doing supporting the learning. Educational Psychologist, 26(3-4), 369-398.

Celce-Murcia, M. \& Olshtain, E. (2000). Discourse and Context in Language Teaching. Cambridge: Cambridge University Press.

Cenoz, J. (2009). Towards Multilingual Education: Basque Educational Research from an International Perspective. Bristol: Multilingual Matters.

Council of Europe (2001). Common European Framework of Reference for Languages: Learning, Teaching, Assessment. Cambridge: Cambridge University Press.

Davis, L. (2009). The influence of interlocutor proficiency in a paired oral assessment. Language Testing, 26(3), 367-396.

Dörnyei, Z. \& Murphey, T. (2003). Group Dynamics in the Language Classroom. Cambridge: Cambridge University Press.

Ellis, R. (2003). Task-based Language Learning and Teaching. Oxford: Oxford University Press.

$<$ e-Adventure $>$ (2011). Centro Aragonés de Tecnologías para la Educación. Retrieved from http://catedu.es/webcatedu/index.php?option $=$ com content\&view $=$ article\&id $=353 \&$ Itemid $=95$

Estaire, S. \& Zanón, J. (1994). Planning Classwork: $\bar{A}$ Task-based Approach. Oxford: Macmillan Heinemann.

Fried-Booth, D. L. (1997). Project work. (8th ed.). Oxford: Oxford University Press.

Fulcher, G. (2003). Testing Second Language Speaking. Harlow: Pearson/Longman.

García Mayo, M. P., Lázaro Ibarrola, A. \& Liceras, J.M. (2005). Placeholders in the English interlanguage of bilingual (Basque/English) children. Language Learning, 55(3), 445-489.

Harmer, J. (1982). What is communicative? ELT Journal, 36(3), 164-168.

Harmer, J. (2007) The Practice of English language Teaching. (4 ${ }^{\text {th }}$ ed.). Harlow: Pearson/Longman.

Herrera, H. (1999). Is the English test in the Spanish University Entrance Examination as discriminating as it should be? Estudios Ingleses de la Universidad Complutense, 7, 89-107.

Hornero, A., Mur-Dueñas, P. \& Plo, R. (2013). Oral skills in the spotlight: EFL in secondary education in a Spanish local context. Synergy 9(2), 111-124.

Jones C. (1986). It's not so much the program, more what you do with it: The importance of methodology in CALL. System, 14(2), 171-178.

Krashen, S. D. (1985). The Input Hypothesis: Issues and Implications. New York: Longman.

Krashen, S. D. (2003). Explorations in Language Acquisition and Use. Portsmouth, NH: Heinemann.

La competencia en comunicación lingüistica en el aula: Experiencias en Aragón. (2013). Retrieved from http://www.unizar.es/ice/index.php/publicacion-de-actas. Instituto de Ciencias de la Educación de la Universidad de Zaragoza y Dirección General de Política Educativa y Educación Permanente. Departamento de Educación, Universidad, Cultura y Deporte del Gobierno de Aragón.

Littlewood, W. (2004). The task-based approach: Some questions and suggestions. ELT Journal, 58(4), 319-326.

Long, M. (1991). Focus on form: A design feature in language teaching methodology. In K. deBot, R. Ginsberg \& C. Kramsch (Eds.). Foreign Language Research in Cross-cultural Perspective (pp. 39-52). Amsterdam: Benjamins.

Long, M. \& Robinson, P. (1998). Focus on form: Theory, research and practice. In C. Doughty and J. Williams (Eds.), Focus on Form in Second Language Classroom (pp. 15-41). New York: Cambridge University Press. 
Muñoz, C. (2003). Variations in oral skills development and age of onset. In M. P. García Mayo and M. L. García Lecumberri (Eds.), Age and the Acquisition of English as a Foreign Language (pp. 161-181). Clevedon: Multilingual Matters.

Mur-Dueñas, P., Plo, R. \& Hornero, A. (2013). Spanish secondary school students' oral competente in EFL: Self-assessment, teacher assessment and tasks. Miscelánea 47, $103-124$.

Nation, I.S.P. \& Newton, J. (2009). Teaching ESL/EFL Listening and Speaking. New York: Routledge.

Palacios, I. M. (1995). A study of the learning strategies used for secondary school and university students of English in Spain. Revista Alicantina de Estudios Ingleses, 8, 177-193.

Palacios, I. M. (2002). Adquisición de segundas lenguas. De la teoría a la práctica pedagógica. In C. Fernández Santás (Coord.). La lengua, vehículo cultural multidisciplinar (pp. 131-172). Madrid: Ministerio de Educación, Cultura y Deporte.

Pérez Torres, I. (2007). Webtasks. Retrieved from http://www.isabelperez.com/taller1/webtasks.htm.

Plo, R. \& Pérez-Llantada, C. (2010). A longitudinal attitude survey on English oral skills: Classroom, curriculum, learning and pedagogical implications. Studium, 16, 309-326.

Rost, M. (1994). Introducing Listening. London: Penguin.

Rost, M. (2005). L2 listening. In E. Hinkel (Ed.). Handbook of Research in Second Language Teaching and Learning (pp. 503-527). Mahwah, NJ: Lawrence Erlbaum.

Salaberry, M.R. (2001). The use of technology for second language learning and teaching: A retrospective. The Modern Language Journal, 85(1), 39-56.

Sinclair, J. McH. \& Coulthard, R. M. (1975). Towards an Analysis of Discourse. The English Used by Teachers and Pupils. Oxford: Oxford University Press.

Swain, M. (2000). The output hypothesis and beyond: Mediating acquisition through collaborative dialogue. In J. P. Lantolf (Ed.), Sociocultural Theory and Second Language Learning (pp. 97114). Oxford: Oxford University Press.

Swain, M. (2005). The output hypothesis: Theory and research. In E. Hinkel (Ed), Handbook of Research in Second Language Teaching and Learning (pp. 471-483). Oxford: Oxford University Press.

Thornbury, S. (2005). How to Teach Speaking. Harlow: Longman.

Tomlinson, B. \& Ávila, J. (2011). Web 2.0: A vehicle for humanising FLL. Anglistik. International Journal of English Studies, 22(1), 137-151.

Tragant, E. \& Muñoz. C. (2000). La motivación y su relación con la edad en un contexto escolar de aprendizaje de lengua extranjera. In C. Muñoz (Ed.), Segundas lenguas: Adquisición en el aula (pp. 81-105). Barcelona: Ariel. 
